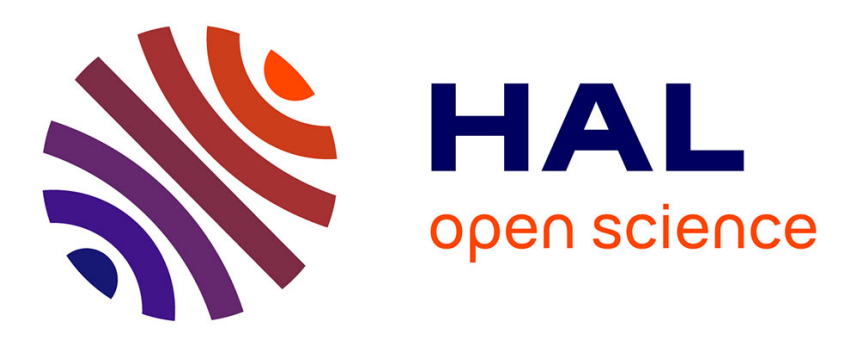

\title{
Persistence of Salmonella Senftenberg in poultry production environments and investigation of its resistance to desiccation
}

\author{
Tina Brønnum, John Elmerdahl Olsen, Magne Bisgaard
}

\section{- To cite this version:}

Tina Brønnum, John Elmerdahl Olsen, Magne Bisgaard. Persistence of Salmonella Senftenberg in poultry production environments and investigation of its resistance to desiccation. Avian Pathology, 2008, 37 (04), pp.421-427. 10.1080/03079450802216561 . hal-00540118

\author{
HAL Id: hal-00540118 \\ https://hal.science/hal-00540118
}

Submitted on 26 Nov 2010

HAL is a multi-disciplinary open access archive for the deposit and dissemination of scientific research documents, whether they are published or not. The documents may come from teaching and research institutions in France or abroad, or from public or private research centers.
L'archive ouverte pluridisciplinaire HAL, est destinée au dépôt et à la diffusion de documents scientifiques de niveau recherche, publiés ou non, émanant des établissements d'enseignement et de recherche français ou étrangers, des laboratoires publics ou privés. 


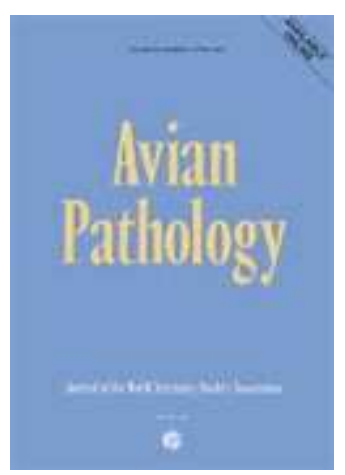

\section{Persistence of Salmonella Senftenberg in poultry production environments and investigation of its resistance to desiccation}

\begin{tabular}{|r|l|}
\hline Journal: & Avian Pathology \\
\hline Manuscript ID: & CAVP-2007-0060.R3 \\
\hline Manuscript Type: & Original Research Paper \\
\hline Date Submitted by the \\
Author: & 16 -Apr-2008 \\
\hline Keywlete List of Authors: & $\begin{array}{l}\text { Brønnum, Tina; University of Copenhagen, Faculty of Life Sciences, } \\
\text { Department of Veterinary Pathology } \\
\text { Olsen, John; University of Copenhagen, Faculty of Life Sciences, } \\
\text { Department of Veterinary Pathology } \\
\text { Bisgaard, Magne; University of Copenhagen, Faculty of Life } \\
\text { Sciences, Department of Veterinary Pathology }\end{array}$ \\
\hline & Salmonella, poultry, persistence, desiccation \\
\hline
\end{tabular}

\section{SCHOLARONE}

Manuscripts 
Cavp-2008-0060.R3

Persistence of Salmonella Senftenberg in poultry production environments and investigation of its resistance to desiccation

Tina Broennum Pedersen ${ }^{1 *}$, John Elmerdahl Olsen ${ }^{1}$ and Magne Bisgaard ${ }^{1}$

${ }^{1}$ Department of Veterinary Pathobiology, Faculty of Life Sciences, University of Copenhagen, Stigbøjlen 4, DK-1870 Frederiksberg C, Denmark

Short Title: Salmonella Senftenberg in poultry production

*Corresponding author. Department of Veterinary Pathobiology, Faculty of Life Sciences, Copenhagen University, Stigbøjlen 4, DK-1870 Frederiksberg C, Denmark, Phone: + 45353334 28, Fax: + 45352827 57, email: tbp@life.ku.dk

Received 9 April 2008 
Cavp-2008-0060.R3

Persistence of Salmonella Senftenberg in poultry production environments and investigation of its resistance to desiccation

Tina Broennum Pedersen ${ }^{1 *}$, John Elmerdahl Olsen ${ }^{1}$ and Magne Bisgaard ${ }^{1}$

\begin{abstract}
Most Salmonella serovars, including Salmonella enterica subsp. enterica serovar Senftenberg (S. Senftenberg), are tolerant to desiccation and able to colonise and persist in feed mills. In addition, they may survive cleaning and disinfection procedures used on poultry farms. This study was conducted to investigate the survival of $S$. Senftenberg in broiler parent stock (PS) farms and broiler farms. The isolates from one of the parent stock farms investigated only differed by a single band in fluorescent amplified fragment length polymorphism analysis (AFLP) and had identical pulsed field gel electrophoresis (PFGE) profiles, indicating that a $S$. Senftenberg clone had persisted for more than two years, despite cleaning, disinfection, desiccation and depopulation, and was subsequently able to infect Salmonella free layers. Isolates from the same house on a different broiler PS farm were found to be identical by AFLP and PFGE although the farm tested negative for Salmonella 55 times over a period of 18 months between the two positive samplings. An assay was developed to investigate the survival of $34 S$. Senftenberg isolates during desiccation at approximately $38 \%$ relative humidity. On average, the viability of $S$. Senftenberg isolates decreased by 1000 fold over 35 days. The persistent clones were not any more resistant to desiccation than the other isolates investigated. However, $S$. Senftenberg was more resistant to desiccation than an isolate of Pantoea agglomerans commonly found on poultry feed processing lines. This study demonstrates the risk of persistence of feed-associated serovars such as $S$. Senftenberg.
\end{abstract}




\section{Introduction}

Salmonella enterica subsp. enterica serovar Senftenberg ( $S$. Senftenberg) is frequently isolated from feed raw materials, the processing line and environmental samples from feed factories and from poultry farms (Bailey et al., 2001; Nesse et al., 2003; Anonymous, 2006a; Broennum et al., 2007b). In addition, S. Senftenberg has been associated with several foodborne outbreaks of salmonellosis in humans (Rushdy et al., 1998; Mohle-Boetani et al., 2001).

The routes of introduction of Salmonella into a broiler flock include vertical transmission from Salmonella infected parent flocks, persistence in the environment and contaminated feed (Bisgaard, 1998). In 1994 Denmark implemented EU directive 92/117/EEC ("the Zoonosis Directive"), under which all breeding stock are tested for $S$. Enteritidis and S. Typhimurium, with elimination of positive flocks. By December 1996, the Danish Salmonella Control Program was extended to include all Salmonella serovars, and eggs from a flock can only be used for production of heated egg products if any Salmonella type is detected. The Danish Poultry Council, in cooperation with feed mills, has run a voluntary HACCP-based hygiene programme that includes heat treatment since 1989 (Bisgaard, 1992) and heat treatment of animal feed became compulsory in 1993. These initiatives resulted in a significant decrease in the prevalence of Salmonella positive broiler flocks and table egg flocks, with current annual prevalences of approximately $2 \%$ and $1 \%$, respectively (Anonymous, 2006a). Surprisingly, the prevalence of isolation exotic serovars has not decreased, indicating that feed and/or the production environment remain significant sources.

S. Senftenberg is able to colonize and persist in feed mills and poultry houses (Wray et al., 1990; Anonymous, 2006a; Anonymous, 2006b; Löfström et al., 2006) and it has been 
suggested that it is more resistant to stresses such as low $\mathrm{pH}$, heating, desiccation and irradiation than other serovars (Liu et al., 1969; Mackey and Derrick, 1982). However, understanding of the reasons for its increased resistance and unambiguous demonstration of its persistence, as demonstrated by molecular typing methods, have been lacking. This study was conducted to investigate how long $S$. Senftenberg might persist in cleaned and disinfected poultry houses and be able to infect new Salmonella-free stock, and to examine whether persistent $S$. Senftenberg isolates survived desiccation better than other $S$. Senftenberg isolates. 


\section{Materials and methods}

Bacterial strains. A total of $34 S$. Senftenberg strains were investigated for persistence using amplified fragment length polymorphism (AFLP) and identical pulsed field gel electrophoresis (PFGE) analysis. The 34 strains included two isolates from 2002 and a single isolate from 2004 from the same farm (Farm 3), as well as two isolates from Farm 4 from January 2000 and July 2001 (Table 1). After slaughter of the S. Senftenberg positive broiler parent stock (PS) on Farm 3 in February 2003, the farm was cleaned, disinfected and remained free of poultry for 10 months until December 2003. Subsequently, Salmonella free stock for table egg production were introduced. Sampling of the flocks was carried out according to national legislation (Anonymous, 2004). In December 2004, the table-egg producing flock tested positive for $S$. Senftenberg, 22 months after the farm had been properly cleaned and disinfected and after six consecutive samples were negative for Salmonella. Two pairs of sock samples, obtained by wearing the socks over the boots during a walk through the entire poultry house (Skov et al., 1999), were collected from each house and 60 eggs were tested each time (Anonymous, 2004)). Another broiler parent flock (Farm 4) tested positive for $S$. Senftenberg approximately three months before slaughter after having tested negative on a weekly basis for 27 weeks. Subsequently, the flock tested negative 10 times until processing. After cleaning, disinfection and dry-out, a subsequent flock tested negative for the whole production period (40 times). A subsequent flock tested negative for five weeks, after which the house again tested positive for $S$. Senftenberg. However, 35 subsequent samplings all tested negative for Salmonella. Full cleaning and disinfection had been carried out in between the flocks. 
Twenty-nine other $S$. Senftenberg isolates, from a variety of epidemiological situations and from different time points (Table 1) were included to investigate diversity. All the $S$. Senftenberg isolates had been serotyped using the Kauffmann White Scheme (Popoff \& Le Minor, 1997). Single isolates of Pantoea agglomerans and Enterobacter purinus were used in the desiccation assay as reference strains. These isolates had been found persisting on a poultry feed processing line (Broennum et al., unpublished data)

Desiccation assay. Pure cultures of all strains were inoculated into $10 \mathrm{ml}$ sterile Luria Bertani (LB) broth (Sambrook et al., 1989) and incubated at $37^{\circ} \mathrm{C}$ for $24 \mathrm{~h}$. Cells from $1 \mathrm{ml}$ of this overnight $(\mathrm{ON})$ culture were harvested by spinning at $15,000 \mathrm{rpm}$ for $5 \mathrm{~min}$ at $4{ }^{\circ} \mathrm{C}$. The pellets were suspended in $1 \mathrm{ml}$ MilliQ-water to avoid salt stress during desiccation. Aliquots of $50 \mu \mathrm{l}$ were added to wells in microtitre trays (Nunc A/S, Roskilde, Denmark). The trays were dried at $37^{\circ} \mathrm{C}$ in an incubation chamber at approximately $70 \%$ relative humidity (RH) for $24 \mathrm{~h}$, after which they were transferred to a desiccator maintained at $38-40 \% \mathrm{RH}$ and at $37^{\circ} \mathrm{C}$ for the remainder of the study (34 days). Culturable cell counts were performed on samples subjected to desiccation for $0,1,2,5,9,15,20$ and 35 days. The desiccated cells were rehydrated by adding $100 \mu \mathrm{l}$ physiological saline, incubating for $10 \mathrm{~min}$ and then mixing by pipetting before plating. Colony forming units (CFU) per ml were calculated by inoculating $10 \mu \mathrm{l}$ samples from tenfold dilution series onto LB agar plates (Sambrook et al., 1989).

AFLP analysis. Strains were grown overnight in LB broth (Sambrook et al., 1989) at $37^{\circ} \mathrm{C}$ and DNA was extracted using the EASY-DNA kit (Invitrogen, Carlsbad, CA, USA). AFLP analysis was performed as described by Torpdahl and Ahrens (2004) using BspDI and 6carboxyfluorescein (FAM) labelled $B g l$ II primers. GeneScan 3.1 fragment analysis software 
(Applied Biosystems, Nærum, Denmark) was used for fragment size determination and pattern analysis. Only AFLP profiles comprising fragments in the size range of 50-500 bp were considered for numerical analysis. This analysis was performed on data files comprising both bacterial AFLP profiles and internal size standards (ABI GeneScan ${ }^{\mathrm{TM}}-500$ ROX, Applied Biosystems, Nærum, Denmark) using the program Gelcompar II version 3.5 (Applied Maths, St. Martens-Latem, Belgium). Normalised AFLP fingerprints were compared using the Dice similarity coefficient and clustering analysis was performed by the unweighted pair group method with arithmetic averages (UPGMA). AFLP fingerprints consisting of approximately 65 to 89 fragments per isolate were compared. The arbitrary similarity $\left(\mathrm{S}_{\mathrm{D}}\right)$ cut off level for individual clonal types was set at $98 \%$.

PFGE analysis. PFGE was performed as described by Christensen et al. (1994), using XbaI to digest chromosomal DNA. DNA fragments were separated in 1\% SeaKem GTG agarose (Camprex Bio Science, Copenhagen, Denmark) using the CHEF DRIII system set at $14^{\circ} \mathrm{C}$ and $5.6 \mathrm{~V} / \mathrm{cm}$ with pulses ramping from 1 to $35 \mathrm{~s}$ over $20 \mathrm{~h}$. The DNA fragments were stained with ethidium bromide and photographed with ultraviolet transillumination using a Geldoc 2000 system (BioRad, Herlev, Denmark) and Quantity One 4.0.3 gel (BioRad, Herlev, Denmark) documentation software. The images of the gels were saved in TIFF format and imported into the program Gelcompar II version 3.5 (Applied Maths BVBA). Cluster analysis was performed using the Dice correlation for band matching with a $1 \%$ position tolerance and UPGMA was used to generate a dendrogram describing the relationships between the $S$. Senftenberg isolates. 


\section{Results}

Analysis of persistence by molecular typing. A total number of $34 \mathrm{~S}$. Senftenberg isolates were analysed by AFLP. Cluster analysis generated a dendrogram with all similarities above 84\% (Figure 1). The AFLP profiles consisted of 65 to 89 fragments between 50 and $500 \mathrm{bp}$. Twenty-one isolates made up one large cluster (A) based on an arbitrary threshold point of 98.7\% similarity, and this cluster included isolates obtained from both the farms suspected to have had persistent contamination (Farm 3 and 4), isolates from Farm 1, and isolates from feed raw materials, imported turkey and chicken meat, and imported curry. This cluster could be divided into subclusters A1, A2, A3 and A4. All three isolates from Farm 3 belonged to subcluster A1. Two isolates from 2002 and 2004 (21 and 22, respectively) were identical, while a second isolate from 2002 (24) differed from these two by a single band. Two isolates from imported curry and single isolates from imported chicken and turkey meat shared the same AFLP profile and made up subcluster A2. Nine isolates from a broiler farm (Farm 1) and a broiler breeder farm (Farm 4) made up subcluster A3. Isolates from Farm 1 were obtained between February 2004 and May 2005, while isolates from the breeder farm were obtained between January 2000 and July 2001. Subcluster A4 included isolates from soy, process line samples from a feed mill, and one isolate from Farm 1. These isolates differed by four bands.

Cluster B had $98 \%$ similarity to cluster A and included isolates from imported turkey meat and exported swine meat. Two isolates from poultry feed processing line samples, which grouped together with one isolate from Farm 2, formed cluster C (Figure 1), although there were 16 band differences between these isolates. Isolates in cluster D had least similarity to the other isolates. This cluster also included a feed mill process line isolate and an isolate from Farm 5. However, there were eight band differences between these isolates. 
Cluster E included two highly related isolates from imported chicken meat. In addition to these five clusters, there were single isolates with distinct profiles.

The 34 S. Senftenberg isolates were also subjected to PFGE analysis. A subset of 25 isolates is shown in Figure 2. All isolates from Farm 1 had identical profiles. Likewise, isolates 28 and 33 had identical profiles, as well as isolates 18 and 19 (not shown). PFGE separated the isolates into 15 profiles with less than $90 \%$ similarity (Figure 2). Six clusters (IVI) had greater than $90 \%$ similarity. Isolates in cluster I had identical profiles and included all the isolates obtained from Farm 3. All isolates from Farm 4 (cluster II) were identical, as were those from Farm 1 (cluster III). Isolates from Farm 4 were similar to isolate 34, which was obtained from a sample of soy. Isolates from imported turkey meat in cluster IV were also similar, as were isolates from imported turkey and pig meat in cluster $\mathrm{V}$, and isolates from imported curry and process line samples in cluster VI.

Resistance to desiccation. The mean concentration of viable cells after overnight culture of all the $S$. Senftenberg isolates was $9.64 \log _{10} \mathrm{CFU} / \mathrm{ml}$. After the cells were washed and dispensed into the wells there was a mean loss of viability of approximately $13 \%$, leaving a mean concentration of $9.57 \log _{10} \mathrm{CFU} / \mathrm{ml}$ for the desiccation trial. Over the first 24 hours the concentration of viable cells decreased by $79 \%$ to approximately $8.87 \log _{10} \mathrm{CFU} / \mathrm{ml}$ (Figure 3). After 48 hours there was a further decrease in concentration of only $6 \%$. Over the first 20 days there was an $83 \%$ decrease in the concentration of viable cells and a further decrease of $36 \%$ between days 20 and 35 . Over 35 days of desiccation at $40 \% \mathrm{RH}$, there was a $99.8 \%$ reduction in the concentration of viable cells, to a final concentration of $6.12 \log _{10} \mathrm{CFU} / \mathrm{ml}$.

The variation between isolates increased with duration of desiccation (Figure 3), and the concentration of the different strains at day 35 ranged from 4.22 to $7.77 \log _{10} \mathrm{CFU} / \mathrm{ml}$ (Figure 3). The loss in viability of the three isolates from Farm 3 was less than the mean of all 
the $S$. Senftenberg isolates (data not shown). However, strains isolated from turkey meat (numbers 11 and 14), a feed mill processing line sample (number 27), and a sample of soy (number 32) showed the greatest resistance to desiccation. There was no significant difference in resistance to desiccation between the isolates from the different sources (farms, meat, spices and feed mills). The resistance of the Enterobacter purinus isolate was similar to that of the $S$. Senftenberg isolates, while the Pantoea agglomerans isolate lost viability rapidly and the concentration of viable cells was only $1.3 \log _{10} \mathrm{CFU} / \mathrm{ml}$ after 35 days of desiccation (Figure 3). 


\section{Discussion}

We investigated the persistence of $S$. Senftenberg in poultry environments. The three isolates obtained from Farm 3 over a period of 30 months were identical by PFGE analysis and by AFLP analysis the isolates obtained in July 2002 and December 2004 were identical while a single isolate obtained in August 2002 differed from them by only one DNA fragment. These data suggest that $S$. Senftenberg can persist for very long periods of time. Over this 30 month period, the environment of the poultry house was exposed to detergents, disinfectants and subsequent desiccation. This observation extends those of Davies and Wray (1996), who were able to isolate Salmonella Enteritidis PT4 from floor sweepings and rehydrated wall fabric junctions in an empty poultry house 22 weeks after cleaning and disinfection. However, their characterization relied on serotyping and phage typing, whereas we used two different genotyping methods and serotyping to demonstrate clonality. The ability of $S$. Senftenberg to persist in poultry production facilities and infect subsequent stock was also demonstrated by observations on both Farms 1 and 4 in our study.

Despite the demonstration of persistence of $S$. Senftenberg on Farms 3 and 4, salmonella were not isolated from repeated weekly samples over extended periods. Salmonella were not isolated from the broiler parent flock on Farm 3 during rearing or the first three weeks on the production farm prior to the first positive sample from Houses 1 and 6 in July 2002. The following week, a positive sample was also obtained from House 2, while samples from the other houses were negative. After two weeks of negative samples, a sample from House 1 was again positive, then samples for an additional 12 weeks were negative, followed by a positive sample and a further 13 negative samples. Samples from House 6 were negative every week until the eleventh week after the first positive sample, then this positive sample was followed by 18 negative samples. A total of 55 samples tested negative for 
Salmonella between these two samplings. Similar observations of samples intermittently positive for $S$. Enteritidis and/or $S$. Typhimurium have been reported previously (Gradel \& Rattenborg, 2003; Anonymous, 2006b). The intermittently positive samplings might be explained by either a lack of sensitivity of the sampling and test method, combined with a very low infection pressure (Skov et al., 1999). However, as doses as low as 5 cells (Milner \& Schaffer, 1952) or $10^{2}$ cfu (Van Immerseel et al. 2004) have shown to be able to colonize chickens, the possibility of persistence in a location to which the chickens are infrequently or indirectly exposed should be considered. Age differences in susceptibility to infection (Beal et al, 2004; Van Immerseel et al. 2004) might also partially explain the intermittently positive samplings.

Serovars such as $S$. Senftenberg and $S$. Infantis appear to persist in poultry houses (Gradel \& Rattenborg, 2003; Anonymous, 2006b). These persistent serovars have also been found in raw materials for poultry feed production (Bisgaard, 1998; Anonymous, 2004; Broennum et al. unpublished data). Although Salmonella were not isolated from any finished poultry feed in Denmark over the period in which these isolates were obtained from the farms (Anonymous, 2004; Broennum et al. unpublished data), epidemiological investigations indicate that feed still represents a risk to the poultry industry (Davies et al., 1997; Bisgaard, 1998; Jensen \& Rosales, 2002; Broennum et al. unpublished data). PFGE analysis of isolates from Farms 3 and 4 suggested that they were related to isolates from feed raw materials. Since the isolates from soy were obtained in July 2002 (Feed Mill A) and November 2003 (Feed Mill C) and the isolates from Farm 4 were from January 2000 and July 2001, there does not appear to be any direct link. However, as Feed Mills A, B and C sometimes share bulk imported raw feed materials and as $S$. Senftenberg may persist in bulk feed tanks and other parts of the unclean area of the a feed mill (Nesse et al., 2003; Anonymous, 2006b; Löfström 
et al., 2006), the poultry feed mill might have been contaminated with $S$. Senftenberg from soy products imported prior to 2000. Soy seems to pose a particular risk for Salmonella contamination (Anonymous, 2006a; Broennum et al., unpublished data).

Finished poultry feed and feed raw materials are normally stored at $12-14 \% \mathrm{RH}$ to prevent microbial growth. The water activity $\left(\mathrm{a}_{\mathrm{w}}\right)$ and organic matter in the environment or in feed influence the survival of Salmonella during desiccation (Mattick et al., 2000; Mattick et al., 2001). Other feed ingredients, such as fat, also influence bacterial survival (Greenwood \& Hopper, 1983). Duncan and Adams (1972) suggested that in feeds with similar moisture contents, different ingredients may affect $\mathrm{a}_{\mathrm{w}}$ values, providing different environments for bacterial survival and growth. As the desiccation assay used in this study was based upon dehydration of the cells after washing in MilliQ-water, enhanced survival due to lipids, proteins and cross-protection by adaptation to salt were excluded. Over 35 days of desiccation at $40 \% \mathrm{RH}$, we observed a mean $99.8 \%$ reduction in the concentration of viable cells of the 34 S. Senftenberg isolates. Ha et al. (1998) observed a $66 \%$ decrease in the concentration of Salmonella after 56 days in poultry mash containing soybean meal and a $71 \%$ decrease in mash containing meat and bone meal ( $\mathrm{a}_{\mathrm{w}}$ approx. $0.63 \%$ ). We found that all the $S$. Senftenberg isolates survived better than a Pantoea agglomerans isolate. However, $S$. Senftenberg has not previously been found to persist any longer in poultry feed than $S$. Enteritidis, S. Typhimurium or S. Mbandaka (Davies \& Wray, 1996). The Pantoea agglomerans isolate used in our study has previously been shown to persist over a period of 14 days in the cooler in a processing line producing poultry feed, where the RH of the feed was below $20 \%$ (Broennum et al., unpublished data).

Our desiccation study was performed at $40 \% \mathrm{RH}$ and $37^{\circ} \mathrm{C}$. Thirty-one $S$. Infantis isolates desiccated under similar conditions had comparable losses of viability and the losses in viability at $37^{\circ} \mathrm{C}$ were similar to those seen at $20^{\circ} \mathrm{C}$ over 35 days (Broennum et al., 
unpublished data). Therefore, although our study of resistance of $S$. Senftenberg to desiccation was performed at $37^{\circ} \mathrm{C}$, it may still be indicative of survival in poultry houses, in which ambient temperatures range from $34^{\circ} \mathrm{C}$ to $18^{\circ} \mathrm{C}$ between the introduction of day old chicks and the time of slaughter.

Previous epidemiological studies on the persistence of Salmonella in poultry environments have used serotyping and plasmid profiling (Baggesen et al., 1992; Brown et al., 1992). In our investigation, a combination of fluorescently labelled AFLP and PFGE analysis was used to ensure reliability, as the discriminatory power of typing methods differs between Salmonella serotypes (Liebana et al., 2001a). PFGE of fragments generated by XbaI digestion of genomic DNA has been recognised as a sensitive method for molecular fingerprinting of several Salmonella serotypes (Lyytikainen et al., 2000; Valdezate et al., 2000; Liebana et al., 2001b).

AFLP has previously been used for separation of epidemiologically unrelated isolates within serovars of Salmonella enterica with varying results (Lindstedt et al., 2000; Torpdahl $\&$ Ahrens, 2004). A threshold of greater than $90 \%$ similarity has been used previously to define genetically similar isolates of $S$. Typhimurium DT 126 in fluorescent AFLP studies (Ross \& Heuzenroeder, 2005). However, use of a threshold of 90\% similarity for AFLP analysis of $S$. Senftenberg, did not generate the same clusters as obtained using PFGE, suggesting that the threshold similarity for AFLP analysis must be determined empirically for each organism to enable meaningful biological and epidemiological conclusions to be drawn. In conclusion, $S$. Senftenberg was demonstrated to persist in several poultry production environments for periods of up to 30 months. In addition, we demonstrated that $S$. Senftenberg was relatively resistant to 35 days of desiccation at $40 \% \mathrm{RH}$. Finally, our study highlights the problems associated with reisolation of Salmonella on farms and underlines the 
risk of persistence related to the introduction of feed-associated Salmonella serovars such as S. Senftenberg 


\section{References}

Anonymous (2004). The national Salmonella control programme for the production of table eggs and broilers 1996-2002. The Danish Veterinary and Food Administration.

Ministry of Family and Consumer Affairs 1, 1-73.

http://www.foedevarestyrelsen.dk/Publikationer/Foedevaresikkerhed/forside.htm

Anonymous (2006a). Annual report on zoonoses in Denmark 2005. Danish Institute for Food and Veterinary Research. Ministry of Family and Consumer Affairs.

Anonymous (2006b). Data delivered by The Danish Poultry Council. Danish Meat

Associations. http://www.danskfjerkrae.dk

Baggesen, D.L., Olsen, J.E. \& Bisgaard, M. (1992). Plasmid profiles and phage types of Salmonella Typhimurium isolated from successive flocks of chickens on three parent stock farms. Avian Pathology, 21, 568-579.

Beal, R.K., Wigley, P., Powers, C., Hulme, S.D., Barrow, P.A. \& Smith, A.L. (2004). Age at primary infection with Salmonella enterica serovar Typhimurium in the chicken influences persistence of infection and subsequent immunity to re-challenge. Veterinary Immunology and Immunopathology, 100, 151-164.

Bailey, J.S., Stern, N.J., Fedorka-Cray, P., Craven, S.E., Cox, N.A., Cosby, D.E., Ladely, S. \& Musgrove, M.T. (2001). Sources and movement of Salmonella through integrated poultry operations: a multistate epidemiological investigation. Journal of Food Protection, 64, 1690-1697.

Bisgaard, M. (1992). A voluntary Salmonella control program for the broiler industry, implemented by the Danish Poultry Council. International Journal of Food Microbiology, 15, 3-4, 219-224.

Bisgaard, M. (1998). Mulige sammenhænge mellem regelgrundlag, frivillige handlingsplaner og opnåede resultater på fjerkræområdet. Til "Høring om Salmonella". Arrangeret af teknologiområdet for Folketingets Udvalg for Fødevarer, Landbrug og Fiskeri. 1-6 (In Danish).

Brown, D.J., Olsen, J.E. \& Bisgaard, M. (1992). Salmonella enterica: infection, cross infection and persistence within the environment of a broiler parent stock unit in Denmark. Zentralblatt Bakteriologie, 277, 1, 129-38.

Christensen, J.P., Skov, M.N., Hinz, K.H. \& Bisgaard, M. (1994). Salmonella enterica serovar Gallinarum biovar gallinarum in layers: Epidemiological investigations of a recent outbreak in Denmark. Avian Pathology, 23, 489-501. 
Davies, R.H. \& Wray, C. (1996). Persistence of Salmonella Enteritidis in poultry units and poultry food. British Poultry Science, 37, 589-596.

Davies, R.H., Nicholas, R.A.J., McLaren, I.M. Corkish, J.D., Lanning, D.G. \& Wray, C. (1997). Bacteriological and serological investigation of persistent Salmonella Enteritidis infection in an integrated poultry organisation. Veterinary Microbiology, 58, 277-293.

Duncan, M.S. \& Adams, A.W. (1972). Effects of a chemical additive and of formaldehyde gas fumigation on Salmonella in poultry feeds. Poultry Science, 51, 3, 797-802.

Gradel, K.O. \& Rattenborg, E. (2003). A questionnaire-based, retrospective field study of persistence of Salmonella Enteritidis and Salmonella Typhimurium in Danish broiler houses. Preventive Veterinary Medicine, 56, 4, 267-284.

Greenwood, M.H. \& Hooper, W.L. (1983). Chocolate bars contaminated with Salmonella Napoli: an infectivity study. British Medical Journal, 286, p. 1394.

Ha, S.D., Maciorowskia, K.G., Kwona, Y.M., Jones, F.T. \& Rickea, S.C. (1998). Indigenous feed microflora and Salmonella Typhimurium marker strain survival in poultry mash diets containing varying levels of protein. Animal Feed Science and Technology, 76, 12, 23-33.

Jensen, E.L. \& Rosales, G. (2002). Salmonella Control In Primary Breeders. e-digest, 2, 10, $1-9$.

Liebana, E., Guns, D., Garcia-Migura, L., Woodward, M.J., Clifton-Hadley, F.A. \& Davies, R.H. (2001a). Molecular typing of Salmonella serotypes prevalent in animals in England: assessment of methodology. Journal of Clinical Microbiology, 39, 10, 36093616.

Liebana, E., Garcia-Migura, L., Breslin, M.F., Davies, R.H \& Woodward, M.J. (2001b). Diversity of strains of Salmonella enterica serotype Enteritidis from English poultry farms assessed by multiple genetic fingerprinting. Journal of Clinical Microbiology, 39, 1, 154-161.

Lindstedt, B.A., Heir, E., Vardund, T. \& Kapperud, G. (2000). Fluorescent amplifiedfragment length polymorphism genotyping of Salmonella enterica subsp. enterica serovars and comparison with pulsed-field gel electrophoresis typing. Journal of Clinical Microbiology, 38, 1623-1627.

Liu, T.S., Snoeyenbos, G.H. \& Carlson, V.L. (1969). Thermal resistance of Salmonella Senftenberg 775W in dry animal feeds. Avian Diseases, 13, 611-631.

Lyytikainen, O., Koort, J., Ward, L., Schildt, R., Ruutu, P., Japisson, E., Timonen, M. \& Siitonen, A. (2000). Molecular epidemiology of an outbreak caused by Salmonella 
enterica serovar Newport in Finland and the United Kingdom. Epidemiology and Infection, 124, 185-192.

Löfström, C., Eriksson, J. Aspán, A., Häggblom, P., Gunnarsson, A., Borch, E. \& Rådström, P. (2006). Improvement and validation of RAPD in combination with PFGE analysis of Salmonella enterica ssp. enterica serovar Senftenberg strains isolated from feed mills. Veterinary Microbiology, 114, 345-351.

Mackey, B.M. \& Derrick, C.M. (1982). The effect of sublethal injury by heating, freezing, drying and gamma-radiation on the duration of the lag phase of Salmonella Typhimurium. Journal of Applied Bacteriology, 53, 243-251.

Mattick, K.L., Jørgensen, F., Legan, J.D., Cole, M.B., Porter, J., Lappin-Scott, H.M. \& Humphrey, T.J. (2000). The survival and filamentation of Salmonella enterica serovar Enteritidis PT4 and Salmonella enterica serovar Typhimurium DT104 at low water activity. Applied Environmental Microbiology, 66, 1274-1279.

Mattick, K.L., Jorgensen, F., Wang, P., Pound, J., Vandeven, M.H., Ward, L.R., Legan, J.D., Lappin-Scott, H.M. \& Humphrey, T.J. (2001). Effect of challenge temperature and solute type on heat tolerance of Salmonella serovars at low water activity. Applied Environmental Microbiology, 67, 4128-4136.

Milner, K.C. \& Schaffer, M.F. 1952. Bacteriologic studies of experimental Salmonella infections in chicks. Journal of Infectious Diseases, 90, 81-85.

Mohle-Boetani, J.C., Farrar, J.A., Werner, S.B., Minassian, D., Bryant, R., Abbott, S., Slutsker, L. \& Vugia, D.J. (2001). Escherichia coli O157 and Salmonella infections associated with sprouts in California, 1996-1998. Annals of Internal Medicine, 135, 239-247.

Nesse, L.L., Nordby, K., Heir, E., Bergsjoe, B., Vardund, T., Nygaard, H. \& Holstad, G. (2003). Molecular analyses of Salmonella enterica isolates from fish feed factories and fish feed ingredients. Applied and Environmental Microbiology, 69, 2, 1075-1081.

Popoff, M.Y. \& Le Minor, L. (1997). Antigenic formulas of the Salmonella serovars, $8^{\text {th }}$ Ed. Institute Pasteur, Paris, France: WHO Collaborating Center for Reference and Research on Salmonella.

Ross, I.L. \& Heuzenroeder, M.W. (2005). Use of AFLP and PFGE to discriminate between Salmonella enterica serovar Typhimurium DT126 isolates from separate food-related outbreaks in Australia. Epidemiology and Infection, 133, 4, 635-44. 
Rushdy, A.A., Stuart, J.M., Ward, L.R., Bruce, J., Threlfall, E.J., Punia, P. \& Bailey, J.R. (1998). National outbreak of Salmonella Senftenberg associated with infant food. Epidemiology and Infection, 120, 125-128.

Sambrook, J., Fritsch, E.F. \& Maniatis, T. (1989). Molecular Cloning: A Laboratory Manual 2. Cold Spring Harbor Laboratory Press

Skov, M.N., Carstensen, B., Tornoe, N. \& Madsen, M. (1999). Evaluation of sampling methods for the detection of Salmonella in broiler flocks. Journal of Applied Microbiology, 86, 4, 695-700.

Torpdahl, M. \& Ahrens, P. (2004). Population structure of Salmonella investigated by amplified fragment length polymorphism. Journal of Applied Microbiology, 97, 566573.

Valdezate, S., Echeita, A., Diez, R. \& Usera, M.A. (2000). Evaluation of phenotypic and genotypic markers for characterization of the emerging gastroenteritis pathogen Salmonella Hadar. European Journal of Clinical Microbiological and Infectious Diseases, 19, 275-281.

Van Immerseel, F, De Buck, J., Pasmans, F., Bohez, L., Boyen, F., Haesebrouck, F. \& Ducatelle, R. (2004). Intermittent long-term shedding and introduction of carrier birds after infection of chickens early posthatch with a low or high dose of Salmonella Enteritidis. Poultry Science, 83, 1911-1916.

Wray, C., Todd, N., McLaren, I., Beedell, Y. \& Rowe, B. (1990). The epidemiology of Salmonella infection of calves: the role of dealers. Epidemiology and Infection, 105, 295-305. 
Table 1. S. Senftenberg isolates analysed by AFLP and PFGE and subjected to desiccation

\begin{tabular}{|c|c|c|c|}
\hline Isolate No. & Isolation date & Origin & Remarks \\
\hline 1 & February 2004 & Farm 1 & Isolate from sock sample, broiler production \\
\hline 2 & February 2004 & Farm 1 & Isolate from sock sample, broiler production \\
\hline 3 & March 2004 & Farm 1 & Isolate from sock sample, broiler production \\
\hline 4 & March 2004 & Farm 1 & Isolate from sock sample, broiler production \\
\hline 5 & March 2004 & Farm 1 & Isolate from sock sample, broiler production \\
\hline 6 & November 2004 & Farm 1 & Isolate from sock sample, broiler production \\
\hline 7 & November 2004 & Farm 1 & Isolate from sock sample, broiler production \\
\hline 8 & May 2005 & Farm 1 & Isolate from sock sample, broiler production \\
\hline 9 & May 2005 & Farm 1 & Isolate from sock sample, broiler production \\
\hline 10 & July 2004 & Farm 2 & Isolate from sock sample, broiler production \\
\hline 11 & May 2003 & Imported meat & Turkey meat, import control \\
\hline 12 & October 2003 & Imported meat & Chicken meat, import control \\
\hline 13 & January 2004 & Imported meat & Turkey meat, import control \\
\hline 14 & August 2004 & Imported meat & Turkey meat, import control \\
\hline 15 & December 2004 & Imported meat & Chicken meat, import control \\
\hline 16 & February 2005 & Imported meat & Chicken meat, import control \\
\hline 17 & March 2005 & Imported meat & Turkey meat, import control \\
\hline 18 & March 2003 & Imported spices & Curry \\
\hline 19 & March 2003 & Imported spices & Curry \\
\hline 20 & April 2003 & Meat & Swine meat, export control \\
\hline 21 & July 2002 & Farm 3 & Isolate from sock sample, broiler parent production \\
\hline 22 & December 2004 & Farm 3 & Isolate from sock sample, table egg production \\
\hline 23 & January 2000 & Farm 4 & Isolate from sock sample, broiler parent production \\
\hline 24 & August 2002 & Farm 3 & Isolate from sock sample, broiler parent production \\
\hline 25 & January 2002 & Farm 5 & Isolate from sock sample, broiler parent production \\
\hline 26 & January 2002 & Feed Mill A & Process sample \\
\hline 27 & December 2003 & Feed Mill B & Process sample \\
\hline 28 & January 2004 & Feed Mill C & Process sample \\
\hline 29 & January 2004 & Feed Mill C & Process sample \\
\hline 30 & July 2001 & Farm 4 & Isolate from sock sample, broiler parent production \\
\hline 31 & July 2002 & Feed Mill A & Soy, raw feed material sample \\
\hline 32 & July 2002 & Feed Mill A & Soy, raw feed material sample \\
\hline 33 & November 2003 & Feed Mill C & Process sample \\
\hline 34 & November 2003 & Feed Mill C & Soy, raw feed material sample \\
\hline
\end{tabular}


Figure 1. AFLP fingerprints of 34 S. Senftenberg strains. Dendrogram calculated using

GelCompare II. The broken line indicates the division into clusters based upon $98 \%$ similarity

Formatted: Font: Italic with the Dice coefficient

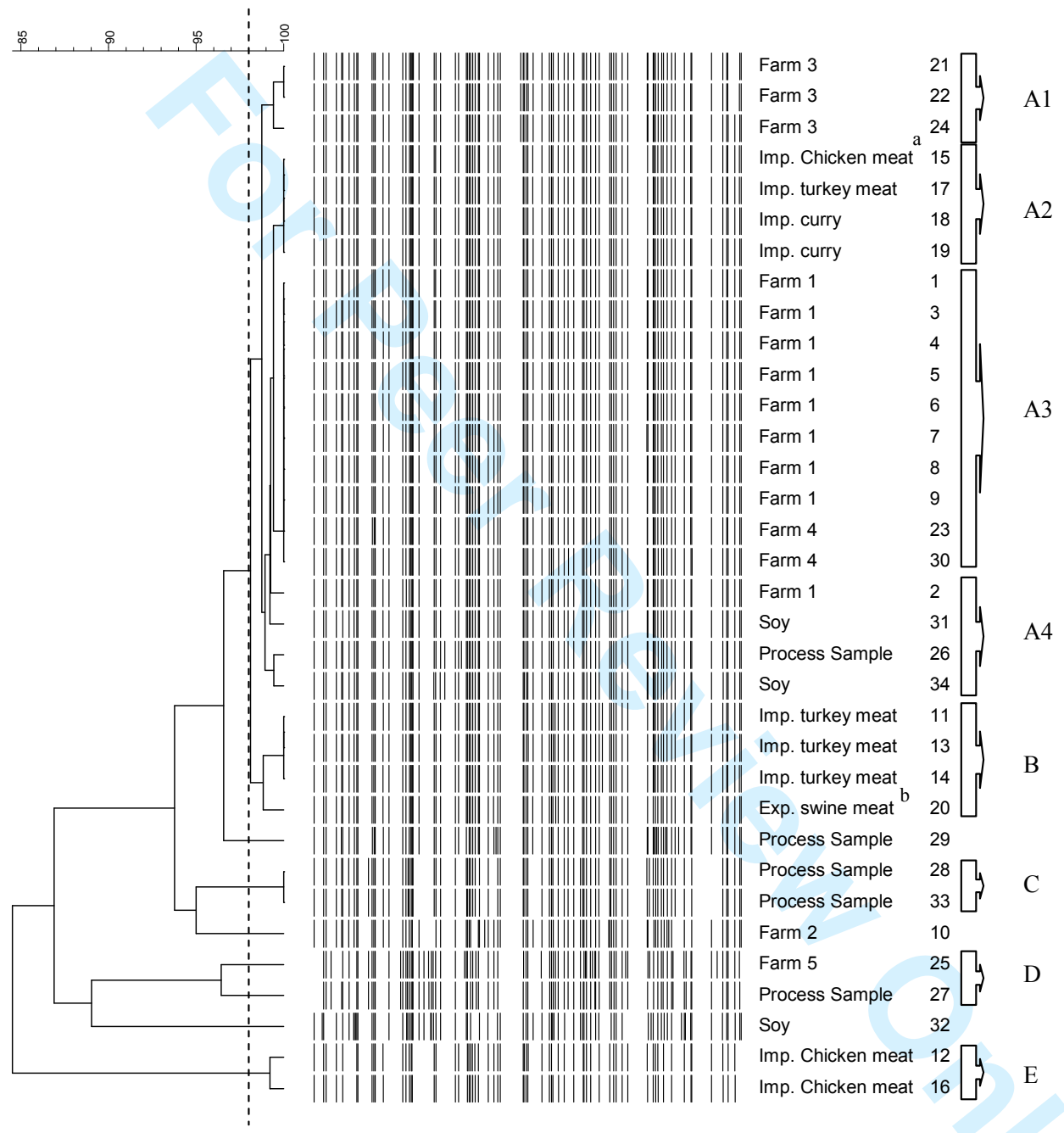

${ }^{\mathrm{a}}$ Imp., imported; ${ }^{\mathrm{b}}$ Exp., exported 
Figure 2. Dendrogram showing PFGE fingerprints from 25 isolates of Salmonella Senftenberg Formatted: Font: Italic representing the total diversity of isolates included in this study. Using the unweighted pair Formatted: Font: Italic group method with arithmetic averages (UPGMA), cluster analysis was performed with the Dice correlation method. The position tolerance was set to $1 \%$ and optimisation was $1 \%$. The broken line indicates the division into clusters made at $90 \%$ similarity with the Dice coefficient
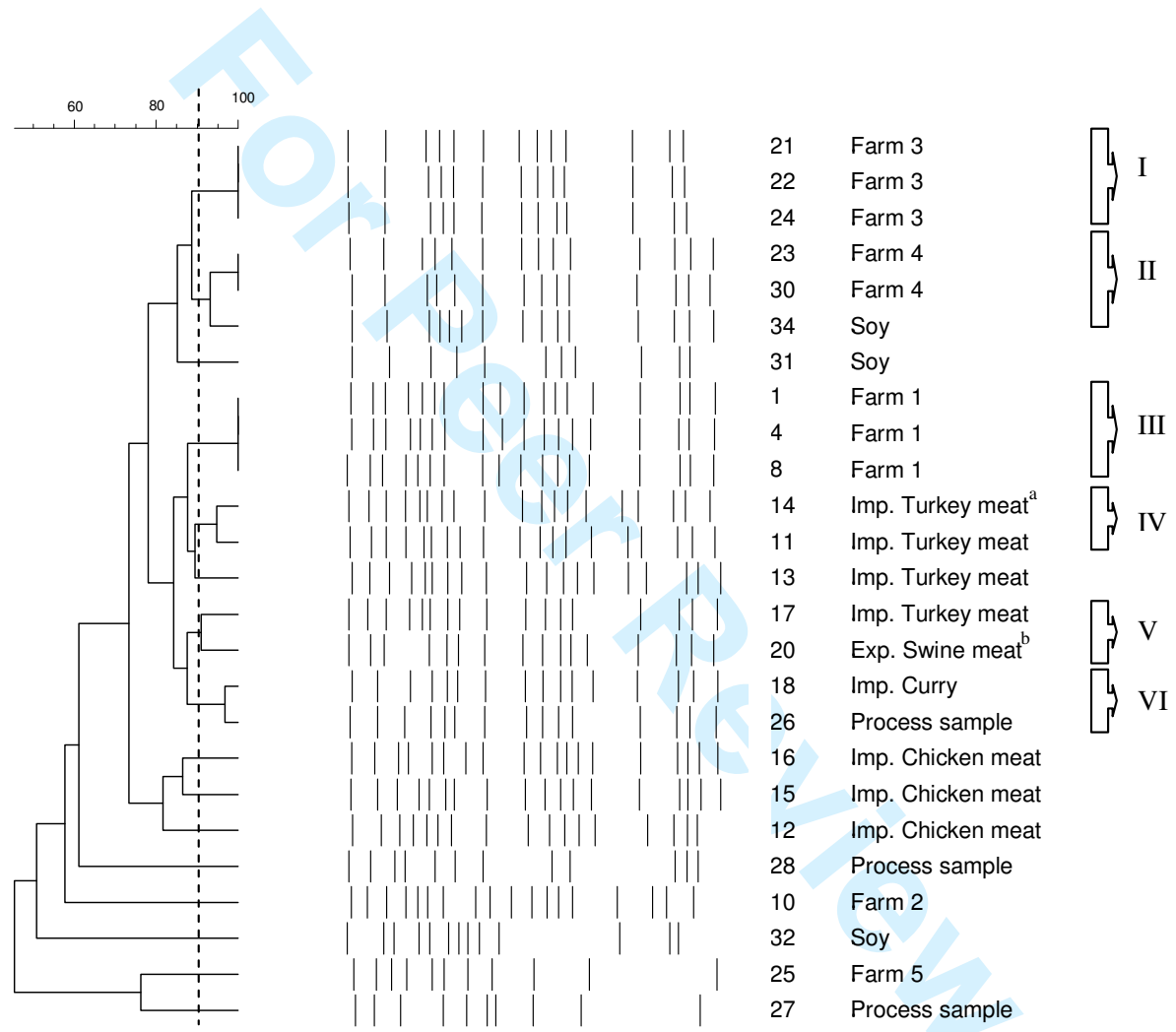

${ }^{\mathrm{a}}$ Imp., imported; ${ }^{\mathrm{b}}$ Exp., exported 
Figure 3. Mean concentrations of 34 isolates of S. Senftenberg (filled square) during desiccation at $40 \%$ relative humidity. The error bars show the range of concentrations. Concentrations of one isolate of Enterobacter pyrinus _open triangle)_and one of Pantoea agglomerans $($ (filled diamond) are also shown

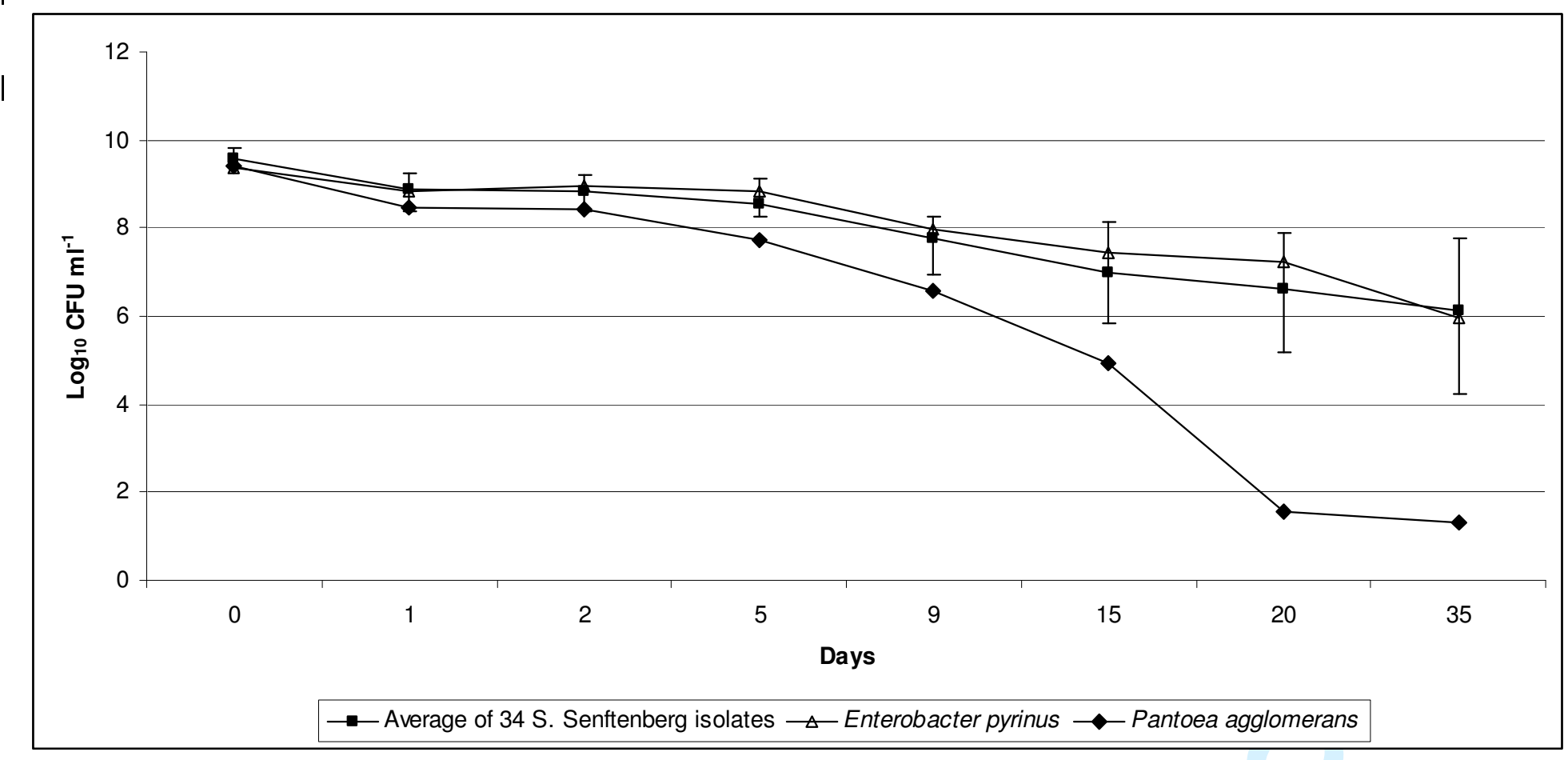

Formatted: Font: Bold Deleted: ull

Formatted: Font: Italic

Formatted: Font: Italic

Formatted: Font: Italic

Formatted: Font: Italic

Deleted: ull 